\title{
Prostatic Cribriform Hyperplasia
}

National Cancer Institute

\section{Source}

National Cancer Institute. Prostatic Cribriform Hyperplasia. NCI Thesaurus. Code C5594.

A rare type of prostatic hyperplasia. It is characterized by hyperplastic glandular cells with clear cytoplasm. 